\title{
Green banking as the prospective dimension of banking in Poland
}

\author{
Anna Laskowska \\ Nicolaus Copernicus University, Faculty of Economic Sciences and Management, \\ Departament of Financial Management, \\ Gagarina 13a St, 87-100 Toruń, Poland, \\ e-mail: annalaskowska@o2.pl
}

Received: 27 September 2017 /Accepted: 9 January 2018

\begin{abstract}
From a global perspective, we can observe a growing interest in environmental protection, also in the banking sector. Through the green banking sector, we can combine two essential benefits - for the economy and nature. The main objective of the paper is to characterise green banking in Poland. Moreover, the paper aims at analysing the representatives of this "green" trend, the motives of financial institutions and the environmental potential for the development of the sector. The presented study compares the involvement of two green banking representatives in the environmental protection (using descriptive and comparative methods and case study). Furthermore, the study predicts the development of this sector (using standardised expert interview). It should be emphasized that the business uses its "green" potential in the area. Ecological aspects are obviously being included in each institution's strategy and banks make profits from the implementation. Pro-ecological activity of banks can be cost-effective in a long-term perspective. The competition in the domain of green banking is constantly growing. It will be increasingly expansive because experts predict the continuation of ecological development of Polish banks.
\end{abstract}

Key words: ecology, ecological financial market, green banking, sustainable banking.

\section{Introduction}

From the global perspective, a constant growth of the interest in environmental protection can be observed on a daily basis. It is no wonder, as human economic activity has an undisputed influence on the nature condition. The issue also has a financial character and can be exemplified by a wide range of "green" financial instruments, as well as the very popular idea of corporate social responsibility (CSR).

The words of Henry Ford, who said "A business that makes nothing but money is a poor business" (Forbes, 2013) argue well the good "green" practices embarked upon by banks. Contemporary financial sector requires its members to implement not only economic aspects into their strategies but also the idea of social responsibility.
The crucial area of the conception is the environmental protection. The consequence - the phenomenon called green banking.

It is interesting that banks, which are widely perceived as aimed at making profits, are to contribute to the improvement of the environment. However, through the green banking sector, we can combine the two essential benefits - for the economy and the nature.

\section{Study area and methods}

The main aim of the article is to characterise green banking in Poland. A closer look on the representatives of the trend will be taken, as well as on the motives for taking up pro-environmental activities by financial institutions. 
Moreover, the piece aims at defining the directions and assessing the environmental potential for the development of the sector.

In order to fulfil the above mentioned goals, the following research approaches will be applied: analysis of the subject literature, data and social responsibility reports; descriptive method, comparative method, case study and standardised expert interview.

The study area includes ecology related strategies of banks in Poland. Attempts to systematise those activities ended up in creating a conventional environmental classification: ecological financial instruments, eco-economy, support activities (marketing, sponsorship, investor relations, public relations) (Dziawgo, 2003).

Basing on the above mentioned categorisation, an analysis of the Polish green banking, taking more visible forms, will be conducted. The undeniable leader is the Bank Ochrony Środowiska [BOŚ Bank], therefore it was deliberately left out as other banks are worth the attention. The involvement in the environment protection of two representatives - Millennium Bank and BGŻ BNP Paribas Bank - will be analysed through both the descriptive and comparative method, as well as the case study. The choice was made due to a wide range of ecological financial instruments (Table 1). The activities in the field of eco-economy and support are executed to a similar extent, therefore the financial offer became a key criterion for the selection.
The opinion of specialists within the area of green banking is worth becoming acquainted with, hence the decision to apply the expert interview, conducted by the author with two members of Sustainable Finance and Accounting Association: Professor Teresa Orzeszko (Wrocław University of Economics associate professor, professional interests: corporate social responsibility of banks and cooperative savings and loan funds) and Dr Marek Szturo (Ph.D. of the University of Warmia and Mazury in Olsztyn, professional interests: eco-innovations, intelligent cities, the role of financial markets in sustainable development) (Sustainable Finance and Accounting Association, http://sfaa.pl).

\section{Philosophical and theoretical basis of green banking}

Financial institutions are the key element of the functioning of local and global communities. The statement relates mainly to banks, which are correlated with different groups concerned. It creates various responsibilities and obligations, including the ecological one, which is reflected in the phenomenon of green banking (Werther \& Chandler, 2006). This is a commitment for the bank to fulfil ecological requirements towards the economy and society, as well as to introduce pro-ecological activities to its strategy - utilising solutions and financial instruments with are friendly

Table 1. Pro-ecological financial products of Millennium Bank and BGŻ BNP Paribas, including respective segments of the banks' clients

\begin{tabular}{|c|c|c|}
\hline & Millennium Bank & BGŻ BNP Paribas Bank \\
\hline $\begin{array}{l}\text { Individual clients } \\
\text { (incl. farmers) }\end{array}$ & WWF Millennium MasterCard credit card & Concordia Auto insurance \\
\hline \multirow{4}{*}{ Personal and private banking clients } & $\begin{array}{l}\text { Participation titles of investment fund } \\
\text { BlackRock GF New Energy Fund }\end{array}$ & \multirow{4}{*}{-} \\
\hline & $\begin{array}{l}\text { Participation titles of investment fund } \\
\text { BlackRock GF World Healthscience Fund }\end{array}$ & \\
\hline & $\begin{array}{l}\text { Participation titles of investment fund } \\
\text { UniAkcje Biopharma }\end{array}$ & \\
\hline & $\begin{array}{l}\text { Participation titles of investment fund } \\
\text { PZU Energy Medicine Ecology }\end{array}$ & \\
\hline \multirow{4}{*}{$\begin{array}{l}\text { Corporate clients } \\
\text { (incl. agricultural producers) }\end{array}$} & Loan for technological innovations & Technological loan \\
\hline & $\begin{array}{l}\text { Polish Sustainable Energy Financing } \\
\text { Facility [PolSEFF] }\end{array}$ & Eko Leasing PolSEFF \\
\hline & Eco Energy Leasing Programme & \multirow{2}{*}{$\begin{array}{l}\text { Investment loan Zielona Energia [Green } \\
\text { Energy] }\end{array}$} \\
\hline & Eco Energy PRO Leasing Programme & \\
\hline
\end{tabular}

Source: elaborated by the author based on reports of Millennium Bank and BGŻ BNP Paribas Bank. 
for the environment. The ecological responsibility is often used to improve economic efficiency and the reputation of an institution (Korenik, 2009).

If the banking sector wants to achieve constant growth and development, it decides to implement strategies, which conduce to greening of the economy (Gabryś, 2015). The greening can be defined as the process of introducing structural changes in the economy aimed at rational exploitation of natural resources, i.e. reduction in water and energy consumption (Famielec, 2015). Contemporarily, the greening widens its spectrum. By virtue of the civilization development, taking cognizance of social factors is essential. Therefore, the greening must constitute an integration of the three grounds: environmental, social and economic. The notion is identified with eco-humanism, i.e. cooperation based on partnership for the good and development of the society, next generations and environment (Michnowski, 2008).

\section{Results and Discussion}

\subsection{Case study}

First of all, the offer of the previously mentioned banks will be evaluated from the perspective of pro-ecological financial products (Table 1).

Millennium Bank offers its individual clients a WWF Millennium Master Card credit card. The product supports the functioning of the international ecological foundation named World Wide Fund for Nature, widely known as WWF. The mechanism of the card is as follows: Millennium Bank transfers a half of the card monthly fee and a part of the commission for each transaction to WWF Foundation's account. Apart from the sponsorship of activities relating to the environment protection (through the cashless payments), the card meets the ecological standards in one more way - it is produced from PETG polyester, which is fully recyclable. It has to be highlighted that the popularity of WWF Millennium MasterCard increases. In 2015 the number of WWF cards in the portfolio was 1,396 whereas in 2016 it was 1,515 (8.5\% growth). It can be seen therefore, that clients are more convinced to ecological instruments carrying out clearing transactions (Millennium Bank, http:// www.bankmillennium.pl/klienci-indywidualni).

The clients of BGŻ BNP Paribas Bank, either farmers or individual entrepreneurs, are offered ecological insurance - the bank serves the role of an insurance agent of Concordia Polska. Through the bank you can purchase Concordia Auto motor insurance, which also includes the ecological risk. The policy guarantees insurance cover against financial loss resulting from environmental damage caused by the transport of harmful substances. Such damage is not usually covered by the compulsory motor insurance, therefore it is worthy for a vehicle transporting substances harmful for the environment to be properly protected, for example through the conclusion of a specialist agreement. Accidents causing the contamination of soil happen and the remedial actions, e.g. land reclamation, are very costly (Laskowska, 2015).

Millennium Bank prepared a different mean to support the environment protection, designed for clients who are willing to pay more - investment funds: BlackRock GF New Energy Fund, BlackRock GF World Healthscience Fund, UniAkcje Biopharma and PZU Energy Medicine Ecology. The above mentioned funds participate in the development of the following pro-ecological sectors: renewable energy, energetic technologies, biotechnologies and healthcare.

Most "green" financial instruments are dedicated to corporate clients. They can benefit from crediting meeting environmental standards. As an example, the recipients of PolSEFF are small and medium companies interested in energetic efficiency, renewable energy and modern technologies. The entrepreneurs can receive investment premiums: $10 \%$ or $15 \%$ PolSEFF financing, when the projects concern renewable energy sources. Examples of investments within PolSEFF are energy and building management systems or installation of photovoltaic collectors (PolSEFF, http:/www.polseff. org/pl/o-polseff).

Leasing programs targeted at corporate clients usually refer to investments in energy-efficient appliances. The aim of the projects is to support Polish companies within the acquisition of technologies reducing the consumption of energy and thus contributing to the environment protection and reduction of costs. In other words, promoting energy-saving entrepreneurship in Poland (Millennium Leasing, 2017).

Another popular ecological instrument, offered by almost every bank, is a loan for technological innovations (including ecological), dedicated to Polish micro, small and medium companies, whereas Zielona Energia [green energy] investment loan is dedicated solely to RES. "Green" crediting is to help in the building of power plants, producing energy from biogas, biomass, wind, water and solar cells.

To sum up, selected banks do not have a well-developed ecological financial offer however, on the background of the Polish banking sector, they still remain leaders. Nevertheless, pro-ecological activities of banks can also be seen in a non-financial spectrum, i.e. ecoeconomy and support actions.

Through a rational use of resources, Millennium Bank minimizes the impact on the nature. The bank regularly publishes detailed indicators connected with the influence on the environment. It should be noted, 
that in 2016, despite the increase in the number of the bank's clients by $9 \%$, a reduction in the use of paper by $4 \%$ could be observed. It resulted from the reduction in the use of resources and re-using materials. It is also worth adding, that in 2016 online bank statements were used by 1.4 million clients, what constitutes $75 \%$ of the overall number. Moreover, in the same year the company reached a $45 \%$ decrease in the waste produced, which in total is managed by a specialist company. It should be noted that $88 \%$ of waste is processed according to recycling policy: energy and material recovery, as well as composting (Millennium Bank, 2017).

BGŻ BNP Paribas Bank also pursues a policy towards the environment other that the financial offer. In order to minimise the exploitation of natural resources and other materials for future generations, the bank implements solutions aimed at the optimizing of its usage. The results of such practices in 2015 were i.a. the reduction of $\mathrm{CO}_{2}$ emission by $30 \%$ (per an employee) and paper usage by $2 \%$ (compared to the previous year). Moreover, the bank also reduces negative impact on the environment for example by waste management - all bank outlets segregate waste. In 2015 the bank utilized 4.2 tonnes of computer equipment in compliance with environmental requirements (BGŻ BNP Paribas Bank, 2017).

Examples of activities, which contributed to the optimization of materials, water, electricity and fuel usage are presented in Table 2.

Table 2. Optimization of materials, water, electricity and fuel usage in Millennium and BGŻ BNP Paribas banks

\begin{tabular}{|c|c|c|}
\hline Product/resource & Millennium Bank & BGŻ BNP Paribas Bank \\
\hline \multirow{6}{*}{$\begin{array}{l}\text { Paper, envelopes, paper rolls for } \\
\text { operational activity }\end{array}$} & Internal transfer of documents & $\begin{array}{l}\text { Internal communication platform via the } \\
\text { Internet }\end{array}$ \\
\hline & $\begin{array}{l}\text { Consolidation of agreements for bank } \\
\text { products }\end{array}$ & Magazines printed on ecological paper \\
\hline & On-line bank statements service & On-line bank statements service \\
\hline & Access to e-administration & "follow me" printing implemented \\
\hline & $\begin{array}{l}\text { The number of envelopes, rolls and } \\
\text { reams of paper ordered subject to } \\
\text { ongoing control }\end{array}$ & Automatic duplex printing \\
\hline & $\begin{array}{l}\text { Wall with graphics in bank outlets } \\
\text { instead of numerous paper posters }\end{array}$ & $\begin{array}{l}\text { "Ecological notifications" which include } \\
\text { the request to verify whether the } \\
\text { particular material requires printing }\end{array}$ \\
\hline Products made of plastic & $\begin{array}{l}\text { A higher limit on safe envelopes and } \\
\text { disposable thermal cups }\end{array}$ & $\begin{array}{l}\text { Drinking water provided in returnable } \\
\text { glass bottles instead of PET }\end{array}$ \\
\hline \multirow{3}{*}{ Water } & Water-saving toilet flushes & Water-saving hydraulic devices \\
\hline & Water diffusers in kitchens and toilets & \multirow[b]{2}{*}{ Ecological programs in dishwashers } \\
\hline & $\begin{array}{l}\text { A system for the collection and } \\
\text { re-circulation of rain water }\end{array}$ & \\
\hline \multirow{4}{*}{ Electricity } & $\begin{array}{l}\text { BREEAM certificate for an ecological } \\
\text { object }\end{array}$ & Energy-efficient electrical devices \\
\hline & Energy-saving LED lighting & Energy-saving LED lighting \\
\hline & $\begin{array}{l}\text { Faster Internet and mobile banking } \\
\text { services reducing electricity consumption }\end{array}$ & Motion detectors for light switches \\
\hline & Virtualization of servers & Regular media usage monitoring \\
\hline \multirow{2}{*}{ Fuel } & Euro 5 standard vehicles & $\begin{array}{l}\text { A program to encourage employees to } \\
\text { ride their bicycles to work }\end{array}$ \\
\hline & $\begin{array}{l}\text { Reduction of business trips thanks to } \\
\text { e-learning and videoconferences }\end{array}$ & $\begin{array}{l}\text { Reduction of business trips thanks to } \\
\text { e-learning and videoconferences }\end{array}$ \\
\hline
\end{tabular}

Source: elaborated by the author based on reports of Millennium Bank and BGŻ BNP Paribas Bank. 
Banks also take up many activities connected with "green" marketing and sponsorship. The event which has already inscribed in the Millennium Bank's responsible strategy, since 2009, is an initiative of WWF Polska foundation called "Earth Hour". The idea of the undertaking is that all lights, advertising panels and banners in the bank outlets are turned off for an hour. Apart from the involvement in the event, the bank also promotes it on the Internet. Ecological Picnic in Nowa Sól can be an example of local sponsorship. These are only two out of numerous instances of the good practices by Millennium Bank in the field of support actions (Millennium Bank, 2017).

BGŻ BNP Paribas Bank, on the other hand, takes part in "Ecoactive" loyalty programme. By recycling the used paper, employees support The Polish Society for the Protection of Birds. Moreover, the bank puts a great emphasis on eco-transport - the institution promotes bicycles as the means of transportation to and from work. For the purpose, the bank organises no car days, bicycle Fridays and bicycle breakfasts. During just one of the events, the participating workers reduced the carbon footprint by 225 kilograms. It should be underlined that bicycle stands outside BGZ BNP Paribas Bank outlets are a guaranteed amenity for clients. Its employees are also entitled to an attended parking for bicycles (BGŻ BNP Paribas Bank, 2017; BGŻ BNP Paribas Bank, http://www.bgzbnpparibas.pl/przedsiebiorstwa).

\subsection{Expert interview}

Selected answers, collected from specified experts during the interviews will be presented below. Initially, the interviews consisted of nine open questions. However, for the purpose of hereby article, only some of them were chosen, aiming at the in-depth analysis of the green banking sector.

The motivation for selecting an expert interview as the research method was the willingness to become familiar with valuable attitudes and predictions regarding the issue of green banking development. The experts who, by definition, have considerable professional achievements and specialist knowledge can afford to form realistic forecasts regarding ecological financial market. The Internet interviews were conducted by the author of the article between 6th and 23rd of May 2017 on a small, thoroughly selected sample. It should be underlined that a limited number of as few as two experts results in the research being for illustrative purposes only.

The following question attempts to provide the answer to what concerns most: Is green banking cost-efficient? Both Professor Orzeszko and Dr Szturo agreed that the answer is not clear-cut. Professor Orzeszko expresses the following view: "Not necessarily in a short-term perspec- tive but in a long-term one definitely yes. However, I understand the term of cost-efficiency in a broader sense not only from the viewpoint of banks but also their clients, including the social benefits".

Dr Szturo takes a similar attitude: “(...) In reference to banks, the implementation of solutions connected with green banking can, in a short-term, have a negative influence on the profitability. However, in time the relation can contribute to the increase in the bank's viability. The improvement is, in a longer period of time, conditioned by how the loyalty of clients is formed, i.e. how to gain ("pull effect") and maintain a sufficient group of clients".

Another issue raised in the expert interview phase is the evaluation of banks' pro-ecological activities on the background of other countries. Professor Orzeszko chooses her words cautiously as "insufficient comparative research within green banking in Poland and other states does not make it possible to perform a reliable assessment".

Dr Szturo, on the other side, is assured that the green banking sector in Poland stands out from other European markets. He explains: "What makes the problems are certain development conditions of the economy. The obstacles seem to be recognized, namely: high costs of the implementation of eco-innovations, the return is fraught with high risk, the system of economic and fiscal incentives offered by the country is insufficient. With such conditioning, the activity of banks within the introduction of proecological financial solutions does not often come upon a favourable ground. When making business decisions, most large banks in Poland are guided not only by the legal requirements or the regulators' expectations but also adopted ethical standards. Can it be stated that the level close to green banking leaders has been reached? In Poland it seems that a certain minimum has been achieved, consisting in the existence of the problem in the market area, mainly due to BOŚ Bank. It is worth adding that the bank's monopoly as the specialist in the promotion of ecoproducts and eco-communication with a client is not undisputed as the competition does not sleep".

Another question refers to the market, which Poland can model on in terms of green banking. Professor Teresa Orzeszko points out particular countries worth being followed in that field: “(...) USA, Great Britain and Australia but also Japan, Malaysia, India and Bangladesh. Banks in Poland should adopt good patterns, proven in foreign banks, yet not uncritically".

The other expert claims that in the sphere of green banking, Poland should follow countries which are our close neighbours, i.e.: "Scandinavian countries (mainly Sweden and Denmark) as well as Germany, also the Netherlands but to a smaller extent. The countries mentioned have similar environmental conditioning and ecological threats. They are being followed by certain challenges, which should be financed by green banks (reducing the 
emission of gasses, changing the economy's carbon footprint, protecting waters including seas etc., switching to renewable energy sources)".

The last question regards the following issue: If the global market gives the development of green banking in the next five years the green light? Professor Orzeszko highlights the importance of society's ecological awareness as well as the stability of economy and legal regulations in the field: "(...) Commercial banks are focused on maximising profits and multiplying the owners' capital, what means that green banking has the chance for positive development only in case of banks with good condition and when the activities in the area are effective and profitable. It should also be noted that society which is well educated in terms of ecology generates clients for banks and may "force" them to undertake "green" actions. In my opinion the activity of banks in Poland within the field of green banking will be continued and it has the chance for a certain development. However, the degree of it depends on many factors, which banks may not necessarily have influence on. They can result from the effects of the society's ecological education, stability and development of economy, stability of law which help to reduce the risk of pro-ecological investments".

Dr Marek Szturo is more optimistic when predicting the evolution of green banking in the next 5 year: "Observers of the financial market can spot a huge market demand for green investments. For example, the research conducted by Accenture and Barclays revealed that the global demand for capital necessary for creating low-emission economy in the next 5 years may reach 4.1 trillion dollars. Visionary banks, both the large and the small ones, see it as an opportunity to take over the green market. For example, Bank of America obliged itself to invest 20 billion dollars to year 2020 in environment-friendly undertakings, such us cleaner energy and green buildings. It should be remembered that the development of green banking is closely related to technological advancement, eco-innovations and global ecological awareness".

The expert interview presented provides solid specialist knowledge in the field of green banking. One may dare to present a few crucial conclusions.

First of all, Dr Szturo underlines that the competition in the sphere of green banking is constantly growing. New pro-environmental bank products are regularly introduced, resulting in the monopoly of BOŚ Bank being threatened. One is for sure - the Republic of Poland should follow the ecological banking practices of other countries such as Australia, Bangladesh Denmark, the Netherlands, India, Japan, Malaysia, Germany, USA and Great Britain. As it can be seen, there is a wide choice of patterns to model. Dr Szturo shares the position of Professor Orzeszko in the area of green banking profitability, that is it can be costeffective in a long-term perspective. It can have a positive effect on the relations between banks and their clients, as well as members of the local community, who very often present high margins of uncertainty towards the "green" practices of financial institutions. Professor Teresa Orzeszko has an antidote to that - sceptical attitude can be change through constant ecological education of citizens and also promoting positive patterns in the field of environmentally responsible banking.

Finally, it is worth emphasizing that answers to the last issue bring an optimistic projection for the evolution of green banking in Poland in the coming years. Experts agree that the development of ecological activity of banks in Poland will be continued. The intensity, though, results from many determinants, which are not dependent on banks, i.a. ecological awareness, technological advancement or the stability of economy and legislation. In other words, green banking will develop, yet the degree of it still remains unknown.

\section{Conclusions}

While analysing the market of ecological bank services, it is necessary to point out that business makes the use of its potential in the area. Ecological aspects are obviously being included in each institution's strategy and banks make profits from the implementation. After in-depth characteristics of green banking in Poland, the aim of the article has been achieved.

A bank, just as any other unit, participates in the arising of social and environmental issues. The duty to repair those inconveniencies is not only a matter of morality but also socially responsible strategy. Other motives of green banking are profitability of undertakings, improvement of the bank's image, legislation, staff's beliefs, competitive position or ecological risk. First of all, it should be remembered that pro-ecological activity of banks is costeffective in a long-term perspective. Despite the fact, that the green behaviour of banks might result from them being self-interested, the influence of staff's beliefs on the actions taken cannot be entirely excluded. Personal opinions and the idea of social responsibility of employees may result in pro-ecological strategies being implemented.

To sum up it should be mentioned that the experts from Sustainable Finance and Accounting Association provide a positive forecast of the development of Polish green banking in the coming few years. It is very good news in reference to the ecological style of life becoming more and more popular, hence the words of Confucius are worth being remembered: "Nature can live without humanity but humanity without nature will perish". It is therefore important to look after the environment in every sphere of life possible, including the financial one. 


\section{References}

BGŻ BNP Paribas Bank, http://www.bgzbnpparibas.pl/ przedsiebiorstwa. [Accessed 28.03.2017].

BGŻ BNP Paribas Bank, 2017, http://www.bgzbnpparibas. pl/raportspoleczny2015/srodowiskowa.html. [Accessed 07.04.2017].

Dziawgo L., 2003, Eco-Offers of Banks and Investment Funds. Poland \& International Trends. Wydawnictwo Uniwersytetu Mikołaja Kopernika, Toruń: 18-20.

Famielec J., 2015, Ekologizacja jako paradygmat rozwoju społeczno-gospodarczego [Green economy as a paradigm of socio-economic development], [in:] M. Kożuch (ed.), Ekologizacja gospodarki [Greening the economy]. Wydawnictwo Uniwersytetu Ekonomicznego w Krakowie, Kraków: 11-30.

Forbes, 2013, http://www.forbes.com/sites/ erikaandersen/2013/05/31/21-quotes-from-henry-fordon-business-leadership-and-life/\#485b2deb293c. [Accessed 18.12.2017].

Gabryś M., 2015, Rola banków w finansowaniu ekologizacji gospodarki gospodarki [The role of banks in greening the economy], [in:] M. Kożuch (ed.) Ekologizacja gospodarki [Greening the economy]. Wydawnictwo Uniwersytetu Ekonomicznego w Krakowie, Kraków: 173-189.

Korenik D., 2009, Odpowiedzialność banku komercyjnego. Próba syntezy [Responsibility of a commer- cial bank. An attempt at synthesis]. Difin, Warszawa: 36-42.

Laskowska A., 2015, Ubezpieczenia ekologiczne w Polsce - determinanty i bariery rozwoju [Environmental insurance policies in Poland - economic growth determinants and barriers], [in:] K. Łyskawa, P. Majewski, D. Walczak (eds), Ubezpieczenia i finanse - nowe perspektywy, Tom IV [Insurance policies and funds - new perspectives, vol. IV]. Polskie Towarzystwo Ekonomiczne, Toruń: 185-195.

Michnowski L., 2008, Ecohumanism as a Developmental Crossing, [in:] S. Sharma, P.K. Sharma (eds.), Transformative Pathways: Attainable Utopias. Prateeksha Publications, Jaipur: 108-136.

Millennium Bank, http://www.bankmillennium.pl/klienciindywidualni/karty-platnicze/karty-kredytowe/wwfmillennium-mastercard\#oplaty. [Accessed 27.03.2017].

Millennium Bank, 2017, http://raportroczny.bankmillennium.pl/2016/pl. [Accessed 27.03.2017].

Millennium Leasing, 2017, http://www.millennium-leasing.pl/leasing-eko-energia. [Accessed 28.03.2017].

PolSEFF, http://www.polseff.org/pl/o-polseff. [Accessed 28.03.2017].

Sustainable Finance and Accounting Association, http:// sfaa.pl. [Accessed 27.05.2017].

Werther W.B. \& Chandler D., 2006, Strategic Corporate Social Responsibility: Stakeholders in a Global Environment, SAGE Publications, Thousand Oaks: 6. 